\title{
JUNO IN THE PROEMIUM OF OVID'S FASTI 6: CONSIDERATIONS ON THE RECONCILIATORY ROLE OF THE GODDESS
}

\begin{abstract}
Summary: In the opening of Fasti 6, Ovid proposes different explanations for the origin of the month name June by means of a competition between three goddesses: Juno, Juventas, and Concordia. Each goddess puts forth an etymology for June that derives from her own name or individual attributions, alimenting the indecisiveness of the poet who eventually walks out of the scene unable to return a verdict. As she is depicted in this text, Juno might appear as a parodic version of the Virgilian goddess and the ideas she represents. To a close reading, however, it is evident that Juno has retained her reconciliatory function, which has allowed the Roman development, and moreover has been enriched by characteristics that look back at her ancient Italian cult and, at the same time, place her in the new Augustan reality. In particular, Ovid blends the early martial and political aspects of the goddess with her function as protectress of legitimate marriage, which seems to have been prominent in the Augustan period. In fact, Ovid emphasizes that conjugal union is the means by which Juno ends her hostility and enables further growth and development.
\end{abstract}

Key words: Parodies of Aeneid, divine contests, Juno's reconciliations, evocatio, archaic Italian religion, Carmen saeculare, Heracles and Hera, Romulus and Titus Tatius, curiae, Concordia Augusta

Virgil's Aeneid contributed to the standardization in literature of specific characteristics of the Roman goddess Juno and moreover provided an aetiological account for the growth of Roman power in the Mediterranean. The final reconciliation of Juno with Jupiter in Aeneid's Book Twelve, with the goddess promising Jupiter to let Aeneas's descendants proliferate and to accept worship from them, represents the final resolution of the discord that prevails since the opening of the poem as well as Juno's commitment to the Roman cause. ${ }^{1}$ Juno's bitter anger manifests itself throughout the Aeneid with the goddess's repeated attempts to hinder Aeneas's mission: in Book One

\footnotetext{
${ }^{1}$ Even though Juno's final reconciliation with Rome lays beyond the poem's conclusion. In the $A e$ neid Juno lets aside her wrath against the Trojans and accordingly allows Aeneas to settle in Latium; but she actually passes to the Roman side only during the Second Punic War - in accordance with the Ennian
} 
she persuades Eolus to raise a storm against the Trojan fleet (1. 50-123); in Book Four she tries to detain Aeneas in Carthage through his bond with Dido (4. 90-172); in Book Five Juno has Iris burn the Trojan ships in Sicily (5. 605-663); and then in Book Seven the goddess unleashes the fury Allecto to destroy the alliance between Trojans and Latins (7. 286-622). Juno's plots, however, clash with the Fates' design to make Aeneas progenitor of the future Roman race, so eventually the goddess submits to her husband's request and allows the Trojans to settle in Latium (12. 791-842; cf. 1. 257-276); but in order to desist from her ferocious persecution Juno exacts a prize from Jupiter - namely, that the Trojans give up their identity and adopt the Latin name and customs - and moreover obtains to be worshipped by the new race above all the other gods (12. 819-828, 833-840; cf. Hor. Carm. 3. 3. 57-68). As Denis Feeney observes, Juno symbolizes a force of chaos and disorder which ultimately leads to the joining of the parts involved. Her disruptive interventions in the Aeneid have both a literary purpose, that is, to contribute to the structural cohesion of the poem itself, and an ideological one: to remind the reader that Rome was built on chaos and violence, which ended through Jupiter's intercession and eventual imposition of order. ${ }^{2}$ This dynamic of wrath and reconciliation mirrors the traditional character of Juno as it had been previously depicted in epic by Homer and Ennius, and is used to explain Juno's subsequent transitions to the Roman side as the goddess willingly abandons one after another her cult cities to permit their absorption into the Roman Empire. As an old enemy of the Trojans (that is, the ancestors of the Romans) and protectress of a number of Mediterranean centres which at some point conflicted with Rome, Juno generally required some form of appeasement and occasionally even a formal invitation to accept worship of her in Rome. ${ }^{3}$ Her successful reconciliation consequently resulted in the final affirmation of the Roman power.

Having briefly illustrated the significance of Juno's function in the Aeneid, I would like to draw the attention now to the opening of Book Six of Ovid's Fasti, a text which condenses and humorously revisits the traditional (and especially Virgilian) characterization of the goddess. In terms of content, the Ovidian text proposes different explanations for the origin of the month name June by means of a competition between three goddesses: Juno, Juventas, and Concordia. Each goddess puts forth an etymology for June that derives from her own name or individual attributions, alimenting the confusion and embarrassment of the poet who eventually walks out of the scene unable to return a verdict. ${ }^{4}$ Compared to the other goddesses' description, the charac-

tradition, which Virgil seemingly followed (cf. Serv. Aen. 1. 281; HoRSFALL 1973-1974, 1-13; FEENEY 1984, 179-194; 1991, 129-134, 146-147).

${ }^{2}$ FEENEY 1991, 150-151; cf. HARDIE 2007, 571-584; COFFEE 2009, esp. 67-73.

${ }^{3}$ The religious ceremony that the Roman magistrates performed to invite the enemies' tutelary deities to Rome was called evocatio. The literary tradition records at least three cases of evocatio with regard to Juno: at Veii (Liv. 5. 21. 1-7), Carthage (Macr. Sat. 3. 9. 7-11), and Perusia (Dio 48. 14. 5-6); PALMER $(1974,15)$ argues for a fourth case at Fidenae. On the ritual of evocatio cf. BEARD-NORTH-PRICE 1998, 34-35, 132-134; FERRI 2010.

${ }^{4}$ This text parallels the divine contest described at the beginning of Book Five, where the poet asks the Muses for help to determine the origin of the name May. Even in this case, the poet is confronted with three possible solutions, but the question remains unsolved (Fasti 5. 1-110. On this portion of Book Five 
terization of Juno in this text is particularly detailed and colourful and, in the past, has been read by some scholars as a criticism, with political implications, of Juno's figure as it emerges from early Augustan poetry. ${ }^{5}$ As I shall demonstrate, however, in spite of several Virgilian references, Ovid's playful portrayal of the goddess does not entail a debasement of her function as defined in the Virgilian epos, nor an opposition to the religious and moral programme advanced by the Augustan regime, which had found one of its highest expressions in the Virgilian epos. On the contrary, a close reading of Ovid's text reveals quite different intentions. I argue that Ovid proposes here a truly Augustan goddess, not only in the sense that his depiction of Juno upholds certain political views, but also in the sense that - comparably to what happens in much literature and art of the time - he presents Juno as a multifaceted and composite creation, which looks at the same time at the Greek tradition, at the ancient Italian and Roman Republican religion, and at aspects of Juno's cult particularly emphasized during the Principate (such as her protection of marriage and childbirth). Also, the reconciliatory function of the goddess, which is so powerfully illustrated in the Aeneid, is not denied in Ovid's text by the undecided final of the proemium, but is in fact reaffirmed through the only apparent disagreement of the three goddesses. My aim is thereby to offer a fresh reading of the verses in question, which may clarify some features of the goddess's portrait and their connection with both the previous literary tradition and the contemporary cultural milieu, and which may overcome strict political interpretations of Ovid's writing.

Book Six of Ovid's Fasti opens with a rather conventional claim to divine inspiration and truthfulness. ${ }^{6}$ The poet then relates how he found himself in a thick and silent grove meditating on the origin of the name June, when three goddesses appeared to him. One was among the goddesses that appeared to Paris on Mount Ida, namely, Juno, "the sister of her husband"; the poet recognizes her by the resemblance with her cult

cf. BARCHIESI 1992, 1-21). Cf. MAZUREK 2010, 128-147, who argues that the contest described in Book Six represents a debate on poetic genres.

${ }^{5}$ Cf., e.g., Fox 1996, 189-190: “Ovid produces a remarkable trivialization of the view of Rome's history put forward in the Aeneid... The terrible wrath which motivates so much of the Aeneid is here made into the jealous whims of a vain and self-deceptive creature"; and Littlewood's comparisons between the goddesses' contest and the domestic feuds in Augustus's family (LITTLEWOOD 2006, 17, for Juno as Livia with her "less-than-cordial relationship with her Julian stepfamily"; partly repeated at 31). On prior political interpretations of Ovid's feelings towards Augustus cf. the influential articles by MCKEOWN (1984, 169-87), and WALLACE-HADRILL (1987, 221-230), who partly criticizes McKeown's position, and BARCHIESI's seminal monograph of 1994, esp. 39-68.

${ }^{6}$ Lines 1-8: Hic quoque mensis habet dubias in nomine causas: / quae placeat, positis omnibus ipse leges. / Facta canam; sed erunt qui me finxisse loquantur, / nullaque mortali numina visa putent. I Est deus in nobis, agitante calescimus illo; / impetus hic sacrae semina mentis habet: / fas mihi praecipue voltus vidisse deorum, / vel quia sum vates, vel quia sacra cano. "Even this month has uncertain origins with regard to its name: you will choose yourself whatever [origin] you like, having laid out them all. I will sing of facts; but there will be those who may say I lied, and think that no divine power was seen by a mortal. There is a god in us, when he stirs we are inspired; this impetus has the seeds of a divine mind: it was especially lawful for me to see the gods' faces, either because I am a poet, or because I sing of sacred matters" (unless otherwise indicated, all translations are my own). 
statue in the Capitoline temple of Jupiter. ${ }^{7}$ The goddess addresses him and, like in a courtroom speech, begins her harangue with a captatio benevolentiae, as she flatters the poet for his literary merit (specifically, for choosing the Roman calendar as the subject of his poem). ${ }^{8}$ To support the assertion that the name June comes from her own, Juno cites as first argument her twofold relation with Jupiter (lines 27-28, 33-34), which the poet has introduced at line 17, and her descent from Saturn (lines 29-30). ${ }^{9}$ In Juno's reasoning, her rank as chief goddess and spouse of Jupiter makes it appropriate to claim a month for herself, especially considering that the month of May was associated with the deity Maia, the mother of Hermes/Mercury through Jupiter - and therefore, a "mistress": an potuit Maio paelex dare nomina mensi, / hic honor in nobis invidiosus erit? ${ }^{10}$ Ovid underscores Juno's status with two means: through the definition of the goddess as soror and coniunx of Jupiter, which is frequently used by Virgil (cf., e.g., Aen. 1. 47, 7. 308, 12. 830, and Ov. Met. 3. 266, 13. 574), ${ }^{11}$ and the attribution of the title regina and of the golden sceptre (lines 37-38), which recalls the Latin roots of Juno's cult. Regina was indeed Juno's official title not only in Rome, but also in the Etruscan city of Veii (from which this cult derived) and Lanuvium, where Juno was worshipped as Juno Sispes (or Sospita) Mater Regina. ${ }^{12}$ The sceptre, on the other hand, commonly characterized the iconography of Capitoline Juno (which is hinted at by the reference to her statue at line 18) and Juno Caprotina. ${ }^{13}$ Thus, in spite of the Virgilian diction, Ovid introduces Juno not primarily as the Virgilian character, but rather as a familiar image to the Roman readers with specific visual connotations taken from Juno's ancient Italian and Roman cults.

Secondly, the allusion to Maia recalls the implacable figure of the Homeric Hera and the pains she is wont to inflict upon Zeus' illegitimate sons or lovers (cf., e.g., Hom. Il. 18. 117-119; Hymn to Apollo 97-101, 305-310). This aspect is unsurprising, since Ovid, in his retelling of Greek myths, often portrays Juno as a wronged wife, especially

${ }^{7}$ Lines 17-18: ex illis [divis] fuit una, sui germana mariti; / haec erat, agnovi, quae stat in arce Iovis.

${ }^{8}$ Cf. LiTTlewood 2006, 12-15. Lines 21-26: O vates, Romani conditor anni, / ause per exiguos magna referre modos, / ius tibi fecisti numen caeleste videndi, / cum placuit numeris condere festa tuis; I ne tamen ignores volgique errore traharis, / Iunius a nostro nomine nomen habet. "O poet, compiler of the Roman year, who have dared to relate great things through thin measures, you gained the right for yourself to see a heavenly power, when you resolved to celebrate the holidays with your verses; but lest you should be unaware and misled by the error of the multitude, June takes its name from mine." For an insightful reading of these opening verses, cf. HERBERT-BROWN 1994, 6-8.

${ }^{9}$ Lines 27-34: Est aliquid nupsisse Iovi, Iovis esse sororem: / fratre magis dubito glorier anne viro. I Si genus aspicitur, Saturnum prima parentem / feci, Saturni sors ego prima fui. (...) Si torus in pretio est, dicor matrona Tonantis, / iunctaque Tarpeio sunt mea templa Iovi. "It is something to be married to Jupiter, to be Jupiter's sister: I doubt whether I should proud myself more on having him as brother or husband. If ancestry is concerned, I was the first to make Saturn father, I was the first offspring of Saturn... If there is a value in marriage bed, I am called the wife of the Thunderer, and my shrines are united to those of Jupiter Tarpeius." Cf. LiTTLEWOOD 2006, 17 about the association of Augustus with Jupiter Tonans.

${ }^{10}$ Lines 35-36: "If a mistress could give her name to the month of May, will this honour be begrudged to me?" On the derivation of May from Maia, see Fasti 5. 81-106; cf. Festus p. 120 L. (134 M.)

${ }^{11}$ Cf. Prauscello 2008, 565-570.

12 PAlmer 1974, 21-32; LitTlewood 2006, 18.

${ }^{13}$ Cf. Palmer 1974, 34; Ov. Fasti 6. 7-19 on the cult of Juno Caprotina. 
in the Metamorphoses (cf., e.g., Met. 2. 508-530, 3. 259-278, 4. 422-431). ${ }^{14}$ Both in this passage - (namely, Fasti 6. 35-36) and others (such as Her. 14. 95; Met. 1. 622 and $726,2.469$ and 508), Juno refers to the victim of Jupiter's lust as a paelex, a term that indicates a mistress or prostitute, and thus a rival to a married woman. Besides conferring an unquestionably comical (and even grotesque) effect to Juno's depiction as a jealous wife who seeks revenge for her husband's various affairs, I would not exclude that Ovid's frequent use of the term paelex in such a context also had a learned connotation. Aulus Gellius, writing in the second century AD, ascribes the following prescription to King Numa Pompilius: paelex aram Iunonis ne tangito; si tanget, Iunoni crinibus demissis agnum feminam ceadito. ${ }^{15}$ Provided that this norm was not Gellius's own fabrication and moreover considering Ovid's vast antiquarian knowledge, it is possible that Ovid, by alluding to a law of Numa, was actually enriching Juno's description with an archaizing Roman colour, and implicitly pointing (though with irony) at the sacrilegious character involved in transgressing the marital bond, of which Juno was the protectress.

The next argument that Juno puts forward in her speech concerns the epithet Lucina: An facient mensem luces, Lucinaque ab illis / dicar, et a nullo nomina mense traham ${ }^{16}$ The argument is evidently flawed, but it is worth noting that Ovid, after having characterized Juno as mighty queen of the gods and a Hera-like frustrated wife, presents now a completely different aspect of her, specifically, as protectress of childbirth; an aspect which is moreover absent from the Virgilian description of Juno. Ovid mentions Juno Lucina in Fasti Books Two and Three with regard to the Lupercalia (February 15) and the Matronalia (Calends of March). Juno Lucina was associated with the origins of both festivals: with the former, because she first gave the instructions, from her sacred grove under the Esquiline, on the ritual to perform in order to enhance female fertility (2. 435-452); with the latter, because the Roman matronae dedicated her a temple after ending the conflict with the Sabines of Titus Tatius (cf. Ov. Fasti 3. 245-258). Ovid relates the name Lucina first to lux ("light") and lucus ("grove"): dedit haec tibi nomina lucis, aut quia principium tu, dea, lucis habes (2. 449-450); and then again to lux: tu nobis lucem, Lucina, dedisti (3. 255). The etymology of "Lucina" from lux is reported by M. Terentius Varro as well, who additionally connects Lucina with the moon (luna), as the moon was believed to help the child's development. ${ }^{17}$ Varro includes Lucina among the deities introduced to Rome by Tatius ( $L L$ 5. 49). Thus, as in the instances considered above, also the mention of Lucina is evocative of a very ancient and popular cult. Furthermore, the cult of Lucina appears to have

${ }^{14}$ I owe the latter observation with respective references to Sophia Papaioannou's presentation.

${ }^{15}$ Gell. NA 4. 3. 3: "A paelex shall not touch the altar of Juno; should she touch it, with her hair let down she shall sacrifice a female lamb to Juno."

${ }^{16}$ Lines 39-40: "Or should daylights make the month, and from those should I be said Lucina, and should I derive my names from no month?"

${ }^{17}$ Thus, according to Varro, the name "Juno Lucina" derived from iuvare ("to help") and luna (Varr. LL 5. 69). Cf. Pliny NH 16. 235: Pliny seems to know only the etymology of Lucina from lucus. On Juno Lucina cf. PALMER 1974, 19-21. For a recent discussion on the Matronalia cf. DoLANSKY 2011, 191-209. 
enjoyed renewed attention at the time of Augustus's enactment of his moral legislation in 18 BC. In the Carmen saeculare, the hymn that Augustus commissioned to Horace to be sung during the celebration of the Secular Games in the following year, the poet addresses a prayer to Lucina so that she might favour the patrum decreta (that is, the marital laws decreed by the senate) and the generation of offspring. ${ }^{18}$ Ovid's mention to Lucina, then, in its combination of archaic flavour and contemporary "re-use", appears as a typical feature of Augustan literature. ${ }^{19}$

After laying out these arguments to prove that she deserves a titulus mensis, the goddess now resorts to threats to obtain June for herself. First, Juno insinuates that she may repent her appeasement with the Trojans (which had been functional to the birth of Rome) and accordingly recalls the motivations of her ancient anger against them. The lines in which Juno explains the twofold origin of her grudge echo very closely, in their phrasing, a famous passage from the Aeneid, as shown below:

\section{Tum me paeniteat posuisse fideliter iras in genus Electrae Dardaniamque domum. Causa duplex irae: rapto Ganymede dolebam, forma quoque Idaeo iudice victa mea est}

Necdum etiam causae irarum saevique dolores exciderant animo: manet alta mente repostum iudicium Paridis spretaeque iniuria formae, et genus invisum, et rapti Ganymedis honores

\author{
(Ov. Fasti 6. 43-44). ${ }^{20}$
}

\section{5}

(Verg. Aen. 1. 25-28). ${ }^{21}$

It is interesting to note that, differently from Virgil, Ovid specifies that the causes of Juno's anger were two (the abduction of Ganymede and the judgment of Paris), but then subtly suggests a third cause as he expands on the Virgilian phrase genus invisum and indicates the genus's progenitors, namely, Electra and Dardanus (line 43). According to the myth, Dardanus was born from the illegitimate union of Jupiter and Electra; so even in this case, as in that of Maia, the Ovidian Juno is concerned with the infidelity of her husband, which she emphasizes by using fideliter, in the previous line, to connote

${ }^{18}$ Cf. Herbert-Brown 1994, 58-59. Hor. Carm. saec. 13-20: Rite maturos aperire partus / lenis Ilithyia tuere matres, / sive tu Lucina probas vocari / seu Genitalis: diva, producas subolem patrumque / prosperes decreta super iugandis / feminis prolisque novae feraci / lege marita. "Duly uncover the ripe offspring, gentle Ilithyia, protect the mothers, either that you approved to be called Lucina or Genitalis: goddess, may you generate offspring, and favour the fathers' decrees about women's marriage and the marital law fruitful of new children."

${ }^{19}$ On this aspect of Ovid poetry, cf. GALINSKY 1996, 261-269.

20 "Then I would repent to have loyally laid aside my wrath against the stock of Electra and Dardanus' house. The cause of my anger was twofold: I grieved since Ganymede was abducted, and also my beauty was defeated because of the judge from Ida." On the causes of Juno's wrath cf. also Hor. Carm. 3. 3. 17-24.

21 "The causes of her anger and savage pains had not yet left her mind: Paris's judgment stays remote in the depth of her heart and the insult of her scorned beauty, and the hateful race, and the fame of Ganymede's abduction." On Ovid's reception of Virgil cf. TARRANT 2002, 13-33; MurGATROYD 2005, 97-140; THOMAS 2009, 294-307. 
her own response to Jupiter's request. Next, Juno warns the poet that she might reconsider her desertion of Carthage and her beloved Greek cities, should he not dedicate her a month in his poem. Three times does Juno threaten to regret her previous choices that permitted the Roman expansion (with paeniteat repeated at lines 41, 45, and 47), and specifically, that she did not favour Carthage even though her paraphernalia are preserved there; ${ }^{22}$ that she allowed the submission to Rome of Sparta, Argos, Mycenae, and Samos; and that she let the Romans conquer the Sabines ruled by Titus Tatius and the Faliscans. ${ }^{23}$

Tatius's attachment to Juno seems confirmed by the ancient literary sources. As noted above, according to Varro Tatius introduced the cult of Lucina to Rome. Dionysius of Halicarnassus ( $R A$ 2. 50. 3) also attributed to Tatius the introduction of the cult of Juno Quiritis, which in Rome was worshipped in the thirty curiae - probably drawing this information from Varro, who indeed makes the term "Quiritis" derive from Cures, the Sabine city ruled by Tatius ( $L L 5.51,6$. 68). At Falerii the cult of Juno seems to have been very old as well; according to Dionysius, this cult descended from that of Hera at Argos and loyally reproduced its rites ( $R A$ 1. 21. 2). Juno's evident affection for her ancient Greek and Italian cult centres (underlined through the use of adjectives such as meae for Mycenae and Iunonicolae for the Faliscans), together with her alleged use of Carthage as a storage for military equipment, highlights Juno's character as a "foreign" goddess potentially hostile to Roman conquest. That the Romans shared this sentiment is shown by the number of evocationes recorded by the literary sources ${ }^{24}$ and by the huge attention given to Juno during the Punic Wars. Livy relates at least four instances in which the goddess's cult was object of special care during the Second Punic War only: before the disaster at Cannae, following a widespread manifestation of portents, the Romans made offerings, in two separate circumstances, to both Juno of Lanuvium and Juno Regina (Liv. 21. 62. 7-8, 22. 1. 17-18); in 207 BC the Roman matronae and maidens performed a procession and an elaborate ritual in honor of Juno Regina (Liv. 27. 37. 7-15 25 ); then, when the trend of the war turned to Roman favour, Hannibal dedicated in turn an altar to Juno Lacinia (Liv. 28. 46. 16; Cic. Div. 1. 24. 48). ${ }^{26}$ At any rate, the prospect of renewed hostility with Rome and the sudden tension that Juno generates with her menacing thoughts is quickly dispelled, as Juno reassures

22 Another borrowing from Virgil: hic illius arma, hic currus fuit (Aen. 1. 16-17).

${ }^{23}$ Lines: 45-50: Paeniteat quod non foveo Carthaginis arces, / cum mea sint illo currus et arma loco; / paeniteat Sparten Argosque measque Mycenas / et veterem Latio subposuisse Samon: / adde senem Tatium Iunonicolasque Faliscos, / quos ego Romanis succubuisse tuli. "I would repent that I do not favour the Carthaginian citadels, when my chariot and armours are in that place; I would repent that I subjected Sparta and Argos and my Mycenae and old Samos to Latium; add the old Tatius and the Juno-worshipper Faliscans, whom I made succumb to the Romans."

${ }^{24}$ Cf. n. 3.

${ }^{25}$ Cf. FEENEY 1984, 193-194.

${ }^{26}$ Cf. also Hor. Carm. 2. 1. 25-28: Juno et deorum quisquis amicior / Afris inulta cesserat impotens / tellure, etc. "Juno and whatever god more favourable to the Africans had withdrawn powerless with the country being unavenged." As Patricia Johnston suggests, the perceived hostility of Juno as Italian goddess may emerge from the Aeneid as well: her wrath in fact increases, in the course of the poem, as the Trojans approach the Italian mainland (JOHNSTON 2002, 123-130). On Hera Lacinia, cf. PALMER 1974, 40-41. 
the poet that she cherishes the Romans above all other races - even though, as the goddess remarks, the absence from the Roman calendar of a month dedicated to her is no match for the magnificent rites she has been granted in the city, nor for the fact that Rome was founded by her very grandson. ${ }^{27}$ To prove her latter point, Juno lists all the Italian cities which, although not founded by Romulus, worship her and have a month for her in their calendars, like Aricia, Laurentum, Lanuvium, Tibur, and Praeneste; and with this remark Juno concludes her talk. ${ }^{28}$

To summarize what I have stated so far, Ovid's portrayal of Juno in the proemium of Book Six emerges, right from the goddess's first appearance, as an idiosyncratic description, which draws and combines elements from a variety of sources. As noted above, Ovid depicts the goddess's epiphany almost as a visual image with well-known traits to the Roman readers; then, Juno's behaviour, with her allusions to Jupiter's infidelities and the mention of her Greek cult centres, evokes closely the figure of the Homeric Hera; third, the frequent reminders to the various Italian cults of Juno (that is, outside Rome) recall both the old conflicts between Rome and the Latins and some ancient features of Juno's cult, conferring an archaizing nuance to the scene. An Augustan touch is given to Juno's description by her characterization as Lucina, the goddess of childbirth invoked in Horace's Carmen saeculare, and overall by the graceful mixing of Roman, Italian and Greek features of different epochs. The Virgilian diction is scattered throughout Ovid's verses and adds a familiar note to Juno's presentation, but there is no slavish reproduction nor mockery of Virgil's poem. Rather, Ovid builds on the Virgilian text to obtain new effects and endow Juno with a more complex personality.

After Juno has concluded her speech, there follow two shorter pleas for the designation of the titulus mensis, delivered in turn by the goddesses Juventas and Concordia.

${ }^{27}$ Lines 51-56: Sed neque paeniteat, nec gens mihi carior ulla est: / hic colar, hic teneam cum Iove templa meo. / Ipse mihi Mavors 'commendo moenia' dixit "haec tibi: tu pollens urbe nepotis eris." / Dicta fides sequitur: centum celebramur in aris, / nec levior quovis est mihi mensis honor. "But may I not repent, nor is there any race dearer to me: here may I be worshipped, here may I hold shrines with my Jupiter. Mars himself said to me 'I entrust these walls to you: you will exert power over the city of your grandson.' Confirmation follows his words: I am celebrated at a hundred altars, nor is a month a lesser honour to me in any way whatever." As Littlewood observes, Juno's claim that she holds the Romans dearer than any other nation and wants to be worshipped there in her husband's temple recalls Jupiter's prophecy in the concluding book of the Aeneid: nec gens ulla tuos aeque celebrabit honores (12. 810; LITTLEWOOD 2006, 20); but this adds a note of disappointment to Juno's claim, for she seems to imply that Jupiter's promise, which helped placate her anger, is actually unfulfilled.

${ }^{28}$ Lines 57-64: Nec tamen hunc nobis tantummodo praestat honorem / Roma: suburbani dant mihi munus idem. / Inspice quos habeat nemoralis Aricia fastos / et populus Laurens Lanuviumque meum: / est illic mensis Iunonius. Inspice Tibur / et Praenestinae moenia sacra deae, / Iunonale leges tempus: nec Romulus illas / condidit, at nostri Roma nepotis erat. "And yet not Rome only pay me this honour: the neighbouring cities offer me the same service. Look at the calendar which woody Aricia has and the nation of Laurentum and my Lanuvium: there is a month of Juno. Look at Tibur and the walls of Praeneste sacred to the goddess, you will read of the time of Juno: nor did Romulus found those, but Rome was of my grandson." Cf. Macr. Sat. 1. 12. 30 about the presence of a month called Junonius in the ancient calendar of Aricia and Praeneste: ut Cingius arbitratur quod Iunonius apud Latinos ante vocitatus diuque apud Aricinos Praenestinosque hac appellatione in fastos relatus sit. 
Juventas was the goddess of youth, commonly identified with the Greek deity Hebe. ${ }^{29}$ In Greek mythology, Hebe was born from Zeus and Hera (Hes. Theog. 921-924) and was given in marriage to Heracles after his apotheosis (that is, after Hera gave up her fierce persecution of the hero). In the Roman tradition as well Juventas was associated with Juno and Hercules, and was believed to look after the youth in army. The latter point is confirmed by Dionysius of Halicarnassus who, quoting the second-century annalist Piso Frugi, relates that King Servius Tullius, wishing to know the number of the people who were born, had died, and reached manhood, ordered that their relatives should pay for each one a certain sum to the treasury of, respectively, Juno Lucina, Venus Libitina, and Juventas, so that he might know every year how many people there were and how many were in military age (Dion. Hal. $R A$ 4. 15. 5). ${ }^{30}$ As for Juventas' relation with Juno and Hercules, Livy tells that the three deities received joint honours during the Second Punic War in 218 BC when, to avert some dread portents, the Romans made a generous offering to Juno at Lanuvium, and in Rome held a lectisternium for Juventas and a special service in the temple of Hercules (Liv. 21. 62. 7-9). Again in the context of the Second Punic War, M. Livius Salinator vowed a temple to Juventas on the day of his victory over Hasdrubal at the river Metaurus (207 BC). The temple was dedicated in the Circus Maximus a few years later by C. Licinius Lucullus, who also vowed public games to the goddess (Liv. 36. 36. 5-6). Seemingly, these games were still staged at the time of Cicero under the supervision of the Luculli (Cic. Att. 1. 18. 3; cf. Brut. 73). The shrine of Juventas was destructed in a conflagration in 16 BC (Dio 54. 19. 7), but Augustus, in his massive renovation program, built it anew (Aug. $R G$ 19).

In his portrayal of Juventas, Ovid does not appear particularly interested in her cult aspects or attributions. Contrarily to Juno, Juventas is not described with any distinct physical features that may help identify her, apart from her lively look, ${ }^{31}$ and is introduced in the text simply as Herculis uxor (line 65), without Ovid ever naming her directly. Juventas as well begins her address to the poet with a captatio benevolentiae; but unlike Juno, the young goddess understates her role and importance, and instead parades humility and gentle disposition. ${ }^{32}$ Juventas' first argument concerns indeed the lack of honors she is given compared to her mother; specifically, Juventas claims that the attribution of June is her only source of prestige, whereas Juno already enjoys a

${ }^{29}$ Cf. Serv. ad Aen. 5. 134: Hebe est Iuventas, uxor Herculis.

${ }^{30}$ That the cult of Juventas could date back to the monarchic period is attested also by Florus, who, in his epitome of Livy, mentions Juventas in relation to the reign of Tarquin the Superb, as the goddess is said to have opposed the removal of her shrine to allow the erection of the temple of Jupiter Optimus Maximus in the same site (Flor. Epit. 1. 7. 8; cf. Liv. 5. 54. 7, who gives a more concise report).

${ }^{31} \mathrm{Cf}$. line 66: in voltu signa vigoris erant.

${ }^{32}$ Lines 67-72: 'non ego, si toto mater me cedere caelo / iusserit, invita matre morabor' ait. / 'Nunc quoque non luctor de nomine temporis huius: / blandior, et partes paene rogantis ago, / remque mei iuris malim tenuisse precando: / et faveas causae forsitan ipse meae.' "I would not stay against my mother's will, should mother order me to depart from the whole heaven, she says. Even now I am not going to fight over this time's name: I speak gently and take the part, as it were, of the petitioner, and I would rather defend my cause independently by praying: and perhaps you may favour my cause yourself." 
splendid cult and shares a temple with her husband on the "golden Capitol." 33 Secondly, Juventas uses the celebrity of her husband to win the poet's sympathy and suggests that a month dedicated to her in the calendar would be an appropriate form of recompense for all the services that Hercules accomplished for the early Romans, such as killing Cacus (lines 78-82). ${ }^{34}$ Juventas' main argument, though, concerns Romulus and his original division of the Roman people according to their age:

\section{Ad propiora vocor: populum digessit ab annis Romulus, in partes distribuitque duas; \\ haec dare consilium, pugnare paratior illa est, haec aetas bellum suadet, at illa gerit. \\ Sic statuit, mensesque nota secrevit eadem: \\ Iunius est iuvenum; qui fuit ante, senum. \\ I call upon more recent events: Romulus organized the population accord- ing to their age, and distributed them in two parts: one is more competent to give counsel, one to fight; the former age-class decides upon war, but the latter wages it. So did he establish, and divided the months with the same criterion: June is of the youth; the month which comes before, of the seniors (Ov. Fasti 6. 83-88)..$^{35}$}

As previously considered, Juventas was associated with the youth in military age (the iuvenes or pars pugnare paratior at line 85). However, the same association is largely attested for Juno as well. First of all, the name itself of Juno could signify "goddess of youth", according to the etymology advanced by Georg Wissowa in the early twentieth century and widely endorsed by modern scholarship. ${ }^{36}$ And secondly, among Juno's

${ }^{33}$ Lines 73-76: aurea possedit socio Capitolia templo / mater et, ut debet, cum Iove summa tenet; at decus omne mihi contingit origine mensis: / unicus est, de quo sollicitamur, honor. "Mother occupies the golden Capitol in her shared temple and, as it is appropriate, dwells on its top with Jupiter; while all my prestige is granted to me through the origin of the month: it is the only honor that I urge." Aurea Capitolia is conceivably a reference to the splendour of the Augustan renovation; the same phrase is used at Verg. Aen. 8. 347-348 (cf. LITTLEWOOD 2006, 25).

${ }^{34}$ In its symbolizing the struggle of good and civilization against evil and savagery, the story of Hercules killing Cacus had become quite popular in the Augustan literature, as its narration by several authors of the time may indicate (cf., e.g., Verg. Aen. 8. 190-279; Ov. Fasti 1. 543-578; Liv. 1. 7. 4; Prop. 4. 9. 1-20; cf. LITTLEWOOD 2006, 26-27).

${ }^{35}$ As we learn from Macrobius, the source of this etymology was the second-century BC fasti of M. Fulvius Nobilior displayed in the temple of Hercules and the Muses, which Fulvius Nobilior dedicated in 189 BC. Macr. Sat. 1. 12. 16: Fulvius Nobilior in fastis quos in aede Herculis Musarum posuit, Romulum dicit postquam populum in maiores iunioresque divisit, ut altera pars consilio, altera armis rem publicam tueretur, in honorem utriusque partis hunc Maium, sequentem Iunium mensem vocasse. "Fulvius Nobilior in the fasti which he set up in the temple of Hercules and the Muses says that Romulus, after he divided the population in seniors and juniors, so that the one part might protect the state with its counsel, the other with the arms, in honour of each part called this month May and the following one June." On the dedication of the temple cf. HARDIE 2007, 560-564.

${ }^{36}$ WISSOWA 1912, 181-182, cited in PALMER 1974, 4. 
oldest cults, those of Juno Quiritis, Juno Populonia (or Populona) and Juno of Lanuvium have all a prominent military character. I mentioned above, in relation to Titus Tatius, that the Sabine king was believed to have introduced to Rome the cult not only of Lucina but also of Juno Quiritis (Dion. Hal. RA 2. 50. 3), and that for Varro the epithet Quiritis derived from Cures (cf. Varr. $L L$ 5. 51, 6. 68). The term Quiritis, however, can also be linked with curis (or quiris, the Sabine word for "spear", cf. Ov. Fasti 2. 477) and curia, that is, each one of the political and military units in which the primitive Roman state was organized. ${ }^{37}$ The latter etymology may be further confirmed by Dionysius, who relates that Tatius dedicated tables to Juno Quiritis in every curia - the tables being still in place at Dionysius' time (Dion. Hal. RA 2. 50. 3).

As for Juno Populonia, while there survive only scattered references in later sources, these highlight the antiquity of her cult and her martial character. This is implicit in her epithet conceivably deriving from populus, a term whose original meaning may indicate the people in army. Secondly, Martianus Capella defines Juno Populonia as a warlike goddess together with Juno Quiritis (Populonam plebes, Curitim debent memorare bellantes; 2. 149); and Augustine, quoting Seneca, tells that Populonia was unmarried - a common characteristic of martial goddesses like Pallas or Artemis (Aug. Civ. Dei 6. 10; cf. Arnob. 3. 30). ${ }^{38}$ The antiquity of Juno Populonia's cult, then, may be inferred by a passage from Macrobius, who quotes a royal law mentioning the temple of the goddess from the Jus Papirianum (that is, the Republican collection of royal laws on religious matters; Macr. Sat. 3. 11). The cult of Juno Sispes of Lanuvium is instead well-known, being abundantly attested by epigraphic and literary sources. The Romans acquired the joint property of her temple and grove in $338 \mathrm{BC}$, when they granted the Roman citizenship to Lanuvium (Liv. 8. 14. 2). ${ }^{39}$ Her iconography is particularly relevant here, as it shows an unquestionably warrior figure. Cicero provides a full description of the goddess's standard attributes: [Sospitam] quam tu numquam ne in somnis quidem vides nisi cum pelle caprina cum hasta cum scutulo cum calceolis repandis. ${ }^{40}$ Juno Sispes is portrayed in this outfit, brandishing her spear, in several cult statues and a number of late Republican coins, such as the denarii of L. Procilius, $80 \mathrm{BC}$ (one of which shows the goddess riding a chariot), L. Papius, $79 \mathrm{BC}$, Q. Cornificius, 44-42 BC, ${ }^{41}$ and M. Mettius, 44 BC. ${ }^{42}$ Hence - going back to Ovid considering the warlike aspects of Juno and her connection with youth, it seems safe

\footnotetext{
${ }^{37}$ The Romans considered these divisions a Romulean institution; Dionysius, in particular, gives a detailed description of Romulus's partition of the population into tribes and curiae (RA 2. 7. 2-4; cf. Cic. Rep. 2. 14; Liv. 1. 13. 6; Plut. Rom. 14. 6, 20. 2) and of the religious duties that Romulus assigned to them (RA 2. 231-235). Those in charge of conducting sacred rites in the curiae were called curiones (Varr. LL 5. 83). Varro proposes an additional etymology for curia, that is, from cura, "care", since in that place the senate "looked after" the interests of the state and there was "care" of the sacrifices (Varr. LL 6. 46). On the origins of the curiae cf. SMITH 2006, 184-234.

${ }^{38}$ On the cult of Juno Populonia, cf. PALMER 1974, 6-7.

${ }^{39}$ On the possible collocation of her archaic temple in Rome, cf. HERBERT-BROWN 1994, 34-43.

${ }^{40}$ Cic. Nat. deor. 1. 82: "[Juno Sospitam] whom you not even in dreams ever see but with the goat skin, with the spear, with the small shield and the flattened half-boots."

${ }^{41}$ Commented on by PALMER 1974, 31.

${ }^{42}$ RRC 379/1-2, 384/1, 472/1, 480/2a, 480/23.
} 
to assume that Juno could represent the Romulean iuvenes just as well as Juventas; and so Juventas' claim that Iunius est iuvenum seems perfectly applicable to Juno, too. Therefore, Juventas' intervention adds an argument in favour of the attribution of the titulus mensis to Juno.

The fact that Ovid never refers to Juventas by naming her directly, but only as the wife of Hercules (lines 65 and 78) deserves some further consideration. This allusion evokes the theme of Juno's persecution of Hercules, and moreover anticipates the narrative, later in the same book, of the encounter between Hercules and Ino - another victim of Juno's wrath - included into the aetiological account of the Matralia. ${ }^{43}$ But it also reminds that Juno is eventually reconciled with Hercules, since Juventas was given in marriage to the hero as a token of such reconciliation. An indirect reference to Juno's appeasement is offered precisely in the story of Ino, where Hercules is called Oetaeus from the place of his death and subsequent apotheosis, which indeed marked the end of Juno's hostility. At the very end of Book Six, the poet refers openly to Juno's appeasement in his address to the Muses: dicite, Pierides, quis vos addixerit isti / cui dedit invitas victa noverca manus (lines 799-800). Hercules is in fact not mentioned by his name, but instead through a periphrasis stating Juno's concession of peace (however reluctant), similarly to what happens in the proemium with Juventas, who is identified not by her name but through her tie with Hercules. ${ }^{44}$ So, Juventas' presence in the proemium, by providing a link with the figure of Hercules, allows the development of the theme of Juno's anger and appeasement in the course of the book, which opens with the hint at Juno's persecution of Hercules and closes by mentioning Juno's reconciliation with the hero. ${ }^{45}$

Juventas finishes speaking, et in litem studio certaminis issent, / atque ira pietas dissimulata foret (lines 89-90). While Juventas has presented herself as a kind and submissive daughter, the poet's concise comment abruptly unmasks her, revealing a hot temper and greed for recognition comparable to that of her mother. This tense

\footnotetext{
${ }^{43}$ Ino was Semele's sister and thus Bacchus's aunt, and was in turn being chased by Juno's wrath. Hercules saved Ino from a throng of frenzied Maenads, whom Juno stirred against her. Lines 518-24: Adpulerat ripae vaccas Oetaeus Hiberas; / audit, et ad vocem concitus urget iter. Herculis adventu quae vim modo ferre parabant / turpia femineae terga dedere fugae. / 'quid petis hinc', (cognorat enim) 'matertera Bacchi? / an numen, quod me, te quoque vexat?' ait. 'Oetan Hercules had driven the Iberian cows to the riverbanks; he heard [Ino], and urges his march rapidly towards her voice. Upon Hercules's arrival those who were just about to carry off violence turned their shameful back to cowardly flight. 'What are you seeking here?' (for he had recognized her) 'Sister of Bacchus's mother? Or the god that vexes me troubles you too?' he said.” On the figure of Ino in Ovid cf. PARKER 1997, 37-72; for a comment on Ovid's passage cf. LITTLEWOOD 2006, 161-163. Juno's persecution of Hercules was a popular theme in literature, and likely provided a precedent for Juno's hostility of Romulus in Ennius's Annales (as demonstrated by FEENEY 1984, 179-184) as well as of Aeneas in Virgil's poem.

${ }^{44}$ Already noted by HARDIE 2007, 566-567.

45 The book closes with the anniversary of the Augustan rededication of the aedes Herculis Musarum. The association of this temple with Juno's reconciliation and Juno's connection with the Muses have been studied by HARDIE 2007, 551-592. The closure of Book Six also marks the concord between the Muses, who at the beginning of Book Five dissented about the name of the month May (cf. LITTLEWOOD 2006, 232).
} 
situation, however, is salvaged by the prompt appearance of the goddess Concordia. Wearing a wreath of laurel on the long mane, the "Apollonian" goddess is described as placidi numen opusque ducis (line 92), with an unequivocal reference to Augustus. ${ }^{46}$ Concordia reports a third etymology for the titulus mensis that allegedly links that name to herself (lines 93-96):

\section{Haec ubi narravit Tatium fortemque Quirinum \\ binaque cum populis regna coisse suis, et lare communi soceros generosque receptos, 'his nomen iunctis Iunius' inquit 'habet.'}

This [goddess] when she had related that Tatius and mighty Quirinus united the two reigns with their populations, and fathers- and sons-in-law were welcomed in a common home, said 'June has its name from their union.'

As Concordia finishes speaking, the poet proclaims his unwillingness to decide and endure the grudge of two offended goddesses. ${ }^{47}$ The etymology that Concordia puts forth is based on the story of Romulus (here called Quirinus from his Augustan identification with this god) and the Sabine ruler Titus Tatius. As the legend has it, these kings merged their two nations after the war caused by the Roman abduction of the Sabine women (on which cf., e.g., Cic. Rep. 2. 12-13; Liv. 1. 9-13; Dion. Hal. RA 2. 31-46; Plut. Rom. 14-19). Through this story, Concordia argues that the name Junius comes from iungere and the union of Romans and Sabines. Considering that Romans and Sabines, before merging their nations, had partly united in marriage, Concordia's etymology for June supposedly alludes to both her own peace-making function and her representing harmonious marriages. In the latter function, Concordia was especially associated, during the late years of the Augustan Principate, with the figure of Augustus's wife Livia. ${ }^{48}$ In spite of Concordia's own connection with marriage, however, the

46 The future emperor Tiberius restored Concordia's temple in 10 AD, so the "peaceful leader" mentioned in this passage could be identified with him as well. The references to the wreath of laurel (on which cf. Aug. $R G$ 4. 34) and the Apollonian character of the goddess, however, have led scholars to prefer the identification of the placidus dux with Augustus (cf. FANTHAM 1986, 262-266; LITTLEWOOD 2006, 31).

${ }^{47}$ Lines 97-100: Dicta triplex causa est. At vos ignoscite, divae: / res est arbitrio non dirimenda meo. / Ite pares a me. Perierunt iudice formae / Pergama: plus laedunt, quam iuvat una, duae. "The origin is threefold. But forgive me, goddesses: the matter is not to be solved through my judgment. Depart as equals from me. Troy was destroyed by a judge of beauty: two goddesses harm more than one delights." Cf. BARCHIESI 1992, 7-9, and especially NEWLAND 1992, 46 on the problematic conclusion of the contest: "[Concordia] simply adds to it by providing yet another etymology, one that in this case honours her. As in so many other human affairs, self-interest is the controlling factor in conditioning belief-a conclusion that was not likely to please Augustus"; a position that NEWLAND substantially maintains at 2002, 248.

${ }^{48}$ Ovid's poem celebrates a few occurrences concerning Concordia, i.e., Camillus's establishment of her first shrine after the plebs' secession, on January 16; Tiberius's dedication of her temple on the same day of $10 \mathrm{AD}$ upon his return from Germany (1.637-50); and Livia's dedication of a shrine to Concordia on the Esquiline on June 11 of 7 BC (6. 637-648; cf. HERBERT-BROWN 1994, 145-156; NEWLAND 
etymology she proposes links the name June not with herself, but specifically with Juno. Festus (who, as it is well-known, draws from the Augustan scholar Verrius Flaccus) relates the verb iungere to Juno Iuga and her supervision of marriages: Iugarius vicus dictus Romae, quia ibi fuerat ara Iunonis Iugae, quam putabant matrimonia iungere (Festus p. 92 L., 104 M.). Virgil indicates the same function for Juno, when he makes her promise Aeolus that he will marry a lovely nymph as a recompense for his service: conubio iungam stabili propriamque dicabo (Aen. 1. 73); and again in Book Four, when Dido, inflamed by love for Aeneas, makes sacrifices to Juno, Iunoni ante omnis, cui vincla iugalia curae. ${ }^{49}$ To the Greeks as well the goddess was known with

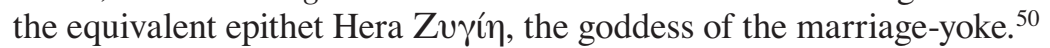

The role of Juno in the conflict between Romans and Sabines becomes clearer if we consider certain previous passages of Ovid's poem. Earlier in Book Six, Juno mentions the old Tatius among those whom she let succumb reluctantly to Roman power (line 49-50). In Book One, Juno is described in her attempt to help the Sabines capture Rome by removing the bars from the city-gate: et iam contigerat portam, Saturnia cuius / dempserat oppositas invidiosa seras (1. 265-266). In this case, Ovid attributes to the goddess the role that had been traditionally of the goddess Discordia: postquam discordia taetra belli ferratos portes / portasque refregit (Ennius frag. 225-226 Skutch). Then, in Book Three, the god Mars recalls the story of the abduction of the Sabine women and subsequent war as an aetiology for the Matronalia (3. 167-257), in which the Roman matronae visited the temple of Juno Lucina and celebrated her rites. In Mars's version of the story, as soon as the Sabines waged war, the abducted - now wedded - Sabine women gathered in the temple of Juno (line 205) and, upon Romulus's wife's advice, placed themselves in-between the two armies lined up for battle. In tears, showing their newborns to fathers and grandfathers, the Sabine women managed to check the imminent battle. On that day the same women (or nurus, daughters-inlaw) founded a temple to Juno on the Esquiline, the one subsequently visited during the festival (lines 246-248). But the real motivation behind the Matronalia, Mars says, is obvious, mater amat nuptas: matris me turba frequentat (line 251).

I suggest that Ovid, through these successive references, is indicating a precise pattern for Juno's conduct. The goddess is a former ally of Titus Tatius and the Sabines,

2002, 225-250; HARDIE 2007, 568-570). In Republican times, the worship of Concordia emerged during moments of major crisis for the state and internal strife: Camillus vowed the temple to Concordia during the struggles of the early fourth century BC between patricians and plebeians; in $121 \mathrm{BC}$ the consul L. Opimius built a shrine to Concordia at the foot of the Capitoline Hill after the severe turbulences caused by the Gracchi's activity; and Cicero summoned the Senate into the same temple in the midst of the Catilinarian crisis. Under Augustus, Concordia's meaning as social and political harmony became especially associated with the imperial household; in fact, the years around the dedications of the two Augustan shrines were marked by a series of bitter events for Augustus's family (cf. LEVICK 1978, 217-233; NEWLAND 2002, 244-249).

${ }^{49}$ In the Aeneid, Juno is also called pronuba when she attends the anomalous marital union of Aeneas and Dido (4. 166), on which line Servius comments: et pronuba Iuno quae nubentibus praeest (Serv. ad Aen. 4. 166).

${ }^{50}$ Cf. FEENEY 1991, 133. 
whom she initially favours. In this, she follows her traditional character, namely, she generates chaos by hindering the Roman victory, just as she does in the Aeneid with the Trojans. However, Juno eventually yields to higher designs, sets aside her hostility, and permits the integration of the Romans with their enemy through marriage bonds. If we consider the stories of Hercules and Juventas (or Hebe), Aeneas and the Latins with Lavinia (but also Aeneas's failed union with Dido and the Carthaginians), and the Romans and the Sabines, marriage turns out as the favourite means by which Juno signals and ratifies her reconciliation. Thus, Concordia's speech, however ambiguous it may sound, is not intended to foment confusion by throwing in a third etymology for June, but is rather a reference to Juno's reconciliatory function as a goddess of marriage. In his chapter on Juno's cult, ${ }^{51}$ Robert Palmer emphasizes the division between the original political and military function of the goddess and - on the other hand - her function as protectress of marriage and female activities, which, as Palmer contends, was not the main aspect of Juno's archaic cult, even though it became prevalent by the early imperial age. Such a division, however, may not be as clear-cut as Palmer presents it. From the accounts considered here on how Juno abandons her resentment and ratifies her reconciliation it may be inferred that Juno's supervision of marriage is not to be relegated among "female activities", but is in fact integral to her martial and political nature, since marriage had itself a political and diplomatic character.

To conclude. I began this contribution by outlining the scheme of anger and reconciliation that characterizes Juno's behaviour in the course of the Aeneid, which is to a large extent applicable to the story of Hercules and the successive transitions of the goddess to Roman side. As she is depicted in the proemium of Book Six of Ovid's Fasti, Juno might appear as a parodic version of the Virgilian goddess and the ideas she represents. To a close reading, however, it is evident that Juno has retained her reconciliatory function, which has allowed the Roman development, and moreover has been enriched by characteristics that look back at her ancient Italian cult and, at the same time, place her in the new Augustan reality. In particular, Ovid has managed to blend the early martial and political aspects of the goddess with her function as protectress of legitimate marriage, which seems to have been prominent in the Augustan period. Indeed, Ovid emphasizes that conjugal union is the means by which Juno ends her hostility and allows further growth and development.

Beatrice Poletti

Dept. of History and Classics

University of Alberta

Edmonton

Canada

${ }^{51}$ PALMER 1974, 3-56. 


\section{BIBLIOGRAPHY}

BARChIESI, A. 1992: Discordant Muses. Proceedings of the Cambridge Philological Society 37, pp. 1-21.

BARCHIESI, A. 1994: Il poeta e il principe: Ovidio e il discorso augusteo. Roma

BEARD, M. -NoRTH, J. - PRICE, S. 1998: Religions of Rome. Vol. 1. Cambridge-New York

CoffeE, N. 2009: Juno's agents and the negotiations of Aeneas. In The Commerce of War: Exchange and Social Order in Latin Epic. Chicago, pp. 67-114.

CRAWFORD, M. H. 1974: Roman Republican Coinage [RRC]. Cambridge

DolAnskY, F. 2011: Reconsidering the Matronalia and Women's Rites. Classical World 104.2, pp. 191-209.

FAntham, E. 1986: Ovid, Germanicus and the Composition of the Fasti. In Adkin, N. - Cairns, F. - Cairns, S. S. - Williams (eds): Papers of the Liverpool Latin Seminar, V 1985. Liverpool, pp. 243-281.

FEENEY, D. C. 1984: The Reconciliations of Juno. The Classical Quarterly, N. S. 34.1, pp. 179-194.

FeEney, D. C. 1991: Vergil's Aeneid. In The Gods in Epic. Poets and Critics of the Classical Tradition, Oxford-New York, pp. 129-187.

FERRI, G. 2010: Tutela urbis. Il significato e la concezione della divinità tutelare cittadina nella religione romana [Potsdamer Altertumswissenschaftliche Beiträge 32]. Stuttgart

Fox, M. 1996: The Regal Period in Ovid's Fasti. In Roman Historical Myths: the Regal Period in Augustan Literature. Oxford-New York, pp. 182-228.

GALINSKY, K. 1996: Augustan culture. An interpretative introduction, Princeton

HARDIE, A. 2007: Juno, Hercules, and the Muses at Rome. American Journal of Philology 128.4, pp. 551-592.

Herbert-Brown, G. 1994: Ovid and the Fasti: An Historical Study. Oxford-New York

HoRSFALL, N. 1973-1974: Dido in the light of history. Proceedings of the Virgil Society 13 , pp. $1-13$.

Johnston, P. A. 2002: The Anger of Juno in Vergil's Aeneid. In Anderson, W. S. Quartarone, L. N. (eds): Approaches to Teaching Vergil's Aeneid. New York, pp. 123-130.

LEvicK, B. 1978: Concordia at Rome. In Carson, R. - Kraay, C. M. (eds): Scripta nummaria romana: Essays Presented to Humphrey Sutherland. London, pp. 217-233.

LitTlewood, R. J. 2006: A Commentary on Ovid, Fasti Book VI. Oxford-New York

MazureK, E. F. 2010: Debating Genre in Ovid's Proem to Fasti 6. Phoenix 64.1/2, pp. $128-147$.

MCKEOWN, J. C. 1984: Fabula proposito nulla tegenda meo. Ovid's Fasti and Augustan Politics. In West, D. - Woodman, T. (eds): Poetry and Politics in the Age of Augustus. Cambridge-New York, pp. 169-187. 
Murgatroyd, P. 2005: Ovid and Virgil. In Mythical and Legendary Narrative in Ovid's Fasti. Leiden, pp. 97-140.

NEWLANDS, C. E. 1992: Ovid's Narrator in the Fasti. Arethusa 25.1, pp. 33-54.

Newlands, C. E. 2002: Contesting Time and Space: Fasti 6. 637-48. In HerbertBrown, G. (ed.): Ovid's Fasti. Historical Readings at Its Bimillennium. OxfordNew York, pp. 225-250.

PALMER, R. E. A. 1974: Juno in Archaic Italy. In Roman Religion and Roman Empire. Five Essays. Philadelphia, pp. 3-56.

PARKER, H. C. 1997: Ino. In Greek Gods in Italy in Ovid's Fasti. Lewiston, NYQueenston, ON, pp. 37-72.

Prauscello, L. 2008: Juno's Wrath Again: Some Virgilian Echoes in Ovid, Met. 3. 253-315. The Classical Quarterly N. S. 58.2, pp. 565-570.

Smith, C. J. 2006: The Roman Curiae. In The Roman Clan. The Gens from Ancient Ideology to Modern Anthropology. Cambridge-New York, pp. 184-234.

TARrant, R. 2002: Ovid and Ancient Literary History. In Hardie, P. R. (ed.): The Cambridge Companion to Ovid. Cambridge-New York, pp. 13-33.

Thomas, R. F. 2009: Ovid's Reception of Virgil. In Knox, P. E. (ed.): A Companion to Ovid. Chichester-Malden, pp. 294-307.

Wallace-Hadrill, A. 1987: Time for Augustus: Ovid, Augustus and the Fasti. In Whitby, L. M. - Hardie, P. R. - Whitby, M. (eds): Homo Viator. Classical Essays for John Bramble. Bristol-Oak Park, pp. 221-230.

WissowA, G. 1912: Religion und Kultus der Römer. München 
